\title{
The Scientific Principle of Food Safety in the Agreement on Sanitary and Phytosanitary Measures
}

\author{
Yusuf Adiwibowo \\ University of Jember, Indonesia \\ yusufadiwibowounej@gmail.com
}

\begin{abstract}
Sanitary and Phytosanitary (SPS) is a procedure to protect human, animal, or plant life or health set in Article XX(b) of the General Agreement on Tariffs and Trade (GATT). This Agreement authorizes the government to arrange a policy, but this domestic measure often results in a trade dispute. Therefore, this study enquires to extent measure on the scientific principle in food safety comply with Article XX (b) GATT. In the context, each WTO Member State has two options to show that measures of handling problems related to SPS are based on science, as outlined in Article XX (b) GATT must be measured by the scientific principle. First, actions can be based on international standards so that each member state must adopt the Codex Alimentarius Commission. Second, actions can be based on Scientific Risk Assessment. SPS Agreement recognizes states' right to maintain standards that are more stringent than international standards, or because international standards do not exist. The relevant scientific principle are useful for measurable events with scientific information beforehand so that the existing measures can guide the state's policy. In vice versa, members may temporarily determine sanitary or phytosanitary actions based on available information.
\end{abstract}

KEYWORDS: Scientific Principle, Food Safety, SPS Measures, WTO.

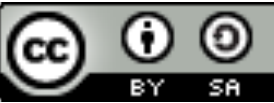

Copyright $\odot 2020$ by Author(s)

This work is licensed under a Creative Commons Attribution-ShareAlike 4.0 International License. All writings published in this journal are personal views of the authors and do not represent the views of this journal and the author's affiliated institutions.

\section{HOW TO CITE:}

Adiwibiwo, Yusuf. "The Scientific Principle of Food Safety in the Agreement on Sanitary and Phytosanitary Measures” (2020) 7:2 Lentera Hukum 171-188.

Submitted: May 16, 2020 Revised: July 23, 2020 Accepted: July 24, 2020 


\section{INTRODUCTION}

International trade has become essential for each country to improve economic growth and development, impacting the level of income and resulting in welfare. This income level can be obtained through production, distribution, export, and import, which affect public income. ${ }^{1}$ Trade intensity and equitable distribution of a country's income are necessary to improve the economic climate through trade between countries. A balanced condition in trade is undoubtedly the hope of every country because it can lead to trade failure without a balanced condition.

History has recorded an economic failure that occurred during a period called the great depression that lasted for a decade from 1929-1939, namely the bankruptcy of the United States economy, caused by stock speculators on financial institutions' support. ${ }^{2}$ However, on the other hand, the American people's purchasing power is low, resulting in an imbalance in the amount of supply that is higher than demand. This condition was exacerbated by the high policy tariff protection import, ${ }^{3}$ which triggered retaliation from other industrialized countries, such as Britain, Italy, Spain, and France, which exacerbated the great depression from 1930 to $1933 .{ }^{4}$ It did not only impact the United States but also European countries as it caused a world recession.

The negotiation was subsequently made to respond to the recession. This negotiation focused on reducing import tariffs, investment, and trade security carried out in Geneva 1948. This event initiated by the United States and 18 other countries agreed to establish the General Agreement on Trade and Tariffs (GATT), which primarily aimed to ensure trade's positive impact through reducing barriers. In 1995, the GATT turned into the World Trade Organization (WTO), which included agreements between member states. Principally, this Agreement produced in the GATT is an effective instrument to liberalize and facilitate trade through national treatment, ${ }^{5}$ Most Favored

1 Sulthon Sjahril Sabaruddin, "The Impact of Indonesia's International Trade on Community welfare: Structural Path Analysis Application "(2015) 17: 4 Bulletin of Monetary Economics and Banking. in Agus Eko Sujianto \& Muhammad Fajar Ulil Azmi, "Associative Study on Government Spending, Inflation, Trade Balance, and Gross Domestic Product" (2020) 15: 1 Equilibrium: Scientific Journal in the Field of Economics 27-37 at 29.

2 Madhusudhanan S, Journal of Business \& Economic Policy, Vol. 1, No. l; June 2014, 35-38 at 25.

3 Laely Armiyati, Great Depression in the United States, Proceedings of the Doctoral Colloquium and Seminar on Grant Research Results 2016 at 265-266.

4 Roth, BJ Ledbetter and DB Roth (Eds.), The Great Depression: A diary. New York, NY: Public Affairs. (2009a) February 13, 1933, Editor's Note. See also Nystrom, Scott Michael, "Free trade and the New Deal: The United States and the international economy of the 1930s". Graduate Theses and Dissertations. Iowa State University, 2010 at 6.

5 The principle of National Treatment is set out in Article 3 GATT, Article 17 of the General Agreement on Trade in Services (GATS), as well as Article 3 of Trade-Related Intellectual Properties (TRIPs) and Friendship, Commerce, and Navigation Treaty (FCN). National treatment is a prohibition for member states to provide different treatment between national companies or national products and foreign companies or products. The imposition of import duties on imports is allowed and exempted from national treatment criteria. However, local products are not subject to the same tax in Sefriani, The Role of International Law in Contemporary International Relations (Jakarta: Rajawali Pers, 2016) at 240. 
Nation (MFN), ${ }^{6}$ non-tariff measures, anti-dumping, ${ }^{7}$ compensation, ${ }^{8}$ and general exceptions. ${ }^{9}$ General exceptions are the exceptions that can be applied to the Most favored nation. There are 11 exceptions regulated in Article XX GATT. One of the material substances of Article XX GATT is Sanitary and Phytosanitary (SPS), which contains safety standards as a procedure that can be applied to protect human, animal, or plant health for WTO member states as regulated in Article XX (b) GATT. ${ }^{10}$ SPS in GATT is a combination of the concept of welfare with safety and health in international trade.

The unique combination of safety and health in a trade is an extension of the precautionary principle first introduced by Germany in 1970, as an effort to "prevent" the "threat of environmental damage that is permanent or can be renewed only at a considerable and long term cost. ${ }^{l l}$ Furthermore, this principle became an agreement announced in the Rio Declaration of 1992 on environment and development, by obliging lawmakers to prevent adverse impacts that are risky to the environment. ${ }^{12}$ The Rio Declaration in Article 15 is known as the precautionary principle, stating, "In order to protect the environment, the precautionary approach shall be widely applied by States according to their capabilities. Where there are threats of serious or irreversible damage, lack of full scientific certainty shall not be used as a reason for postponing cost-effective measures to prevent environmental degradation." ${ }^{\text {13 }}$ The precautionary principle in the Rio Declaration provides legitimacy to

6 The substance of the MFN is that each member must immediately and unconditionally provide no worse treatment to other members. John Kraus, The GATT Negotiation: A Business Guide To The Result of The Uruguay Round, ICC, 1994 at 41 in Sefriani, "International Service Trade Arrangements in GATS/WTO" (2005) 28:12 Journal of Law 129-146 at 136.

7 Dumping is an activity to sell the same (product-like) in another country market at a price below the normal value. Importing countries have the right to collect anti-dumping import duties if there is a material loss to the domestic industry, or at least there is a threat to the sustainability of or hindering the domestic industry's development. KD Raju, World Trade Organization Agreement on Anti-dumping: A GATT / WTO and Indian Jurisprudence (The Netherlands: Kluwer Law International BV, 2008) at 100.

8 Safeguard measures taken by the importing country's government to recover severe losses or prevent the threat of profound loss to the domestic industry due to a surge in imported similar goods or directly competitive goods. In order to overcome these losses, the importing country must be compensated. Carmen G Gonzales, "Institutionalizing Inequality: The WTO Agreement on Agriculture, Food Security, and Developing Countries." (2002) 27: 2 Columbia Journal of Environmental Law 435-489 at 440.

9 José Augusto Fontoura Costa, "Data Protection in International Trade Law" in Dário Moura Vicente \& Sofia de Vasconcelos Casimiro, eds, Data Protection in the Internet Ius Comparatum - Global Studies in Comparative Law (Cham: Springer International Publishing, 2020) 479 at 482.

10 Article XX (b) GATT states it is necessary to protect human, animal, or plant life or health.

II Mary Stevens, "The Precautionary Principle in the International Arena" (2002) 7: 2 Sustainable Development Law \& Policy 13-22 at 13.

12 This declaration was signed at the United Nations Conference on Environment and Development ("UNCED") PEEL, J. 2004. Precaution - A Matter of Principle, Approach, or Process? Melbourne Journal of International Law vol 19; issue 5 (2) pg 483) in Tilak Ginige et al., "Harnessing marine renewable energy from Poole Harbor: a case study" (2013) 6: 1-3 International Journal of Liability and Scientific Inquiry 1-26 at 1.

13 Alice Rocha da Silva \& Mario Abrahão Antônio, "A aplicação do princípio da precaução ante os riscos advindos das novas tecnologias bélicas" (2018) 8: 1 RBPP 745-765 at 755. 
the state to take the necessary actions so that the impact of an environmental problem can be prevented through the formation of laws.

On the other hand, Article XX (b) GATT authorizes the government to set standards in technical regulations, ${ }^{14}$ which must be adjusted to the Agreement on the Sanitary and Phytosanitary (SPS). ${ }^{15}$ Provisions on sanitary relate to human or animal life or health, while phytosanitary deals with plant life or health. ${ }^{16}$ SPS is a substantial way taken in the WTO Agreement in resolving conflicts of interest between states in bridging security and freedom issues in the trade because the social responsibility to protect citizens by the state from threats and risks is the state's responsibility. In the meantime, the SPS Agreement emphasizes that WTO members can protect human, animal, and plant life, ${ }^{17}$ by implementing provisions for managing risks associated with imports, which can be implemented through trade barriers ${ }^{18}$ on the grounds of protecting national interests. Import barriers related to the SPS Agreement on American beef is an example. The European Union has carried it out; the European Union argues that American beef is given an injection of the hormone estradiol, stabilizing, and acetate health problems. ${ }^{19}$ The US and the European Union are trading partners that are bound by the SPS

14 Yusuf Adiwibowo, "Technical Barrier to Trade of Indonesian Kretek Cigarettes in Measures Affecting the Production and Sale of Clove Cigarettes in the United States (DS-406)" (2013) 1: 2 Journal of IUS $235-244$ at 234.

15 See the preamble to the Agreement On The Application Of Sanitary And Phytosanitary Measures, outlining the rules for implementing the GATT 1994 provisions relating to sanitary or phytosanitary measures, in particular, the provisions of Article XX (b).

16 Quarantine Agency, "Overview of Sanitary and Phytosanitary (SPS) Measures," Agricultural Quarantine Agency of the Ministry of Agriculture of the Republic of Indonesia, online: 〈https://karantina.pertanian.go.id/ page-20-sekilas-sps.html.>.

17 The protection of human, animal, and plant life is regulated in the definition of the SPS agreement which states that: "(a) to protect animal or plant life or health within the territory of the member from risks arising from the entry, establishment or spread of pests, diseases, disease-carrying organisms or disease-causing organisms; (b) to protect human or animal life or health within the territory of the member from risks arising from additives, contaminants, toxins or disease-causing organisms in foods, beverages or feedstuffs; (c) to protect human life or health within the territory of the member from risks arising from diseases carried by animals, plants or products thereof, or from the entry, establishment or spread of pests; or (d) to prevent or limit other damage within the territory of the member from the entry, establishment or spread of pests." Benn McGrady, Trade and Public Health: The WTO, Tobacco, Alcohol, and Diet (Cambridge University Press, 2011) at 176.

18 The application of provisions as a protection mechanism can be carried out by a country to prevent trade that is not under the standards set by a country through statutory laws. It is the authority of a country, as stated in Annex A Paragraph 1, "Sanitary or phytosanitary. measures include all relevant laws, decrees, regulations, requirements, and procedures including, inter alia, end product criteria; processes and production methods; testing, inspection, certification and approval procedures; quarantine treatments including relevant requirements associated with the transport of animals or plants, or with the materials necessary for their survival during transport; provisions on relevant statistical methods, sampling procedures and methods of risk assessment; and packaging and labeling requirements directly related to food safety." WTO | Sanitary and Phytosanitary Measures - text of the agreement", online: 〈https://www.wto.org/english/tratop_e/sps_e/spsagr_e.htm〉.

19 Darrell Chichester, "Battle of the Beef, the Rematch: An Evaluation of the Latest EC Directive Banning Beef Produced with Growth Hormones and the US Refusal to Accept the Directive as WTO Compliant" American University International Law Review, Vol. 21, 2005, at 226. Sri Wartini, 'Implementation of the Prudential Principle in the Sanitary and Phytosanitary Agreement, Case Study: WTO Appellate Body Decision in the Case of Hormone Beef Between the European Union and the United States,' Legal Journal, Vol. 14 No. 2, 2007 at 298. 
Agreement. The European Union does not allow the use of Genetically Modified Organisms (GMOs) in Agriculture, ${ }^{20}$ while hormones and animal antibiotics are commonly given in the US. ${ }^{21}$ The two customs of different countries in enforcing specific rules give rise to international trade disputes. The United States considers that the European Union has violated the WTO Agreement by implementing trade barriers.

Trade barriers to the US were resolved in 26 (DS26), ${ }^{22}$ ruling that the European Commission's ban on meat imports was inconsistent and violated Article 3.1 and Article 5 of the SPS Agreement. ${ }^{23}$ The second example is the closure of beef export markets in North America and Canada in 2003, which became contentious because of the beef infected with bovine spongiform encephalopathy. ${ }^{24}$ It was an effort to maintain a reputation that can result in a contaminated country losing its reputation as a producer of safe food for consumers until the outbreak or infection can be overcome. ${ }^{25}$ The United States is well-known as a meat exporting country, so to maintain the quality of meat it exports, the meat industry prepares a strict legal system with standardization set by the country and the WHO to enter the international market.

Another example deals with Indonesia as a reported party in several cases accused of violating the SPS Agreement on meat and horticulture by the United States and New Zealand in (DS477 and DS478). The complainant sued 18 policies regarding Indonesian import licensing for horticultural products, animals, and meat and the adequacy of domestic production needs. Indonesia claims that the implementation of the Ministry

20 GMOs is a business model by carrying out genetic engineering, which functions according to the beneficial objectives of being inserted into one genetic organism. The results of the engineering can overcome unexpected resistance. John Paull, "Genetically Modified Organisms (GMOs) as Invasive Species" (2018) 4: 3 Journal of Environment Protection and Sustainable Development 31-37 at 33.

21 Since the DS26 dispute until the negotiation of the Transatlantic Trade and Investment Partnership (TTIP) agreement between the US and the European Union, there has not been an agreement on using GMOs and hormones. Beckman, Jayson, Shawn Arita, Lorraine Mitchell, and Mary Burfisher. 2015. "Agriculture in the Transatlantic Trade and Investment Partnership: Tariffs, Tariff-Rate Quotas, and Non-Tariff Measures. Washington DC: US Department of Agriculture. "Paper presented at the Agricultural \& $\&$ Applied Economics Association's 2015 AAEA Annual Meeting, San Francisco, California, July 26-28. Economic Research Service (212886) and Office of the US Trade Representative (USTR). 2017. "Transatlantic Trade and Investment Partnership (T-TIP)." https://ustr.gov/ttip. Elham Darbandi, Riza Radmehr \& Sayed H Saghaian, "The Impact of Consumer Beef Safety Awareness on US Beef Exports" (2020) The International Trade Journal, online: 〈https://doi.org/10.1080/08853908. 2020.1742255>.

22 Dispute Settlement Body or DSB is Dispute Resolution Bodies if WTO rules are violated. Steven J Hoffman \& Trygve Ottersen, "Addressing antibiotic resistance requires robust international accountability mechanisms" (2015) 43: 3 The Journal of Law, Medicine \& Ethics.

23 "WTO, Dispute Settlement Understanding - legal text, "online: 〈https://www.wto.org/english/ tratop_e/dispu_e/dsu_e.htm $\$ 26>$.

24 Coffey, B. et al., "The Economic Impact of BSE on the US Beef Industry: Product Value Losses, Regulatory Costs, and Consumer Reactions (Extension Bulletin MF-2678)." Manhattan, KS: Kansas State University Agricultural Experiment Station and Cooperative Extension Service. In Glynn Tonsor et al., "Consumer valuations of beef steak food safety enhancement in Canada, Japan, Mexico, and the United States.", Vol. 57, Issue. 3, August 2009: at 396 "(2009) 57: 3 Canadian Journal of Agricultural Economics / Revue canadienne d'agroeconomie 395-416 at 396.

25 Webb, Mike, John Gibson, and Anna Strutt. "The Impact of Diseases on International Beef Trade: Market Switching and Persistent Effects." Food Policy 75: 93-108. 2018.doi: 10.1016/j.foodpol. 2018.01.006. Ibid. 
of Trade Regulation No. 16/2013, Ministry of Trade Regulation No. 47/2013, Ministry of Agriculture Regulation No. 86/2013, Ministry of Agriculture Regulation No. 139/2014 is justified in Article XX (b) of GATT 1994. The panel conclusions found that Indonesia has failed to prove that policies 1 to 18 are justified according to Article XX (b) of GATT 1994. ${ }^{26}$ In 2014, the government was sued by Brazil regarding regulations on the import of chicken and chicken products. ${ }^{27}$ In 2017, Brazil again challenged Indonesia's beef import regulations. The Indonesian Government suffered defeat in both Brazilian lawsuits. ${ }^{28}$

The use of electronic SPS certificate standards is in line with the International Plant Protection Convention (IPPC) and the Standards and Trade Development Facility (STDF), which applies the e-Phyto Solution applicable to animals and live food, ${ }^{29}$ plant products, ${ }^{30}$ and several other products. ${ }^{31}$ The electronic SPS certificate standard is a facility for quick notification access by authorized agencies and private parties so that adjustments to activities with developing terms and procedures can be communicated.

SPS terms and procedures in the trade as an answer to the question, how can the state ensure that consumers can consume safe and healthy food according to scientific standards, but on the other hand, it must be ensured that trade barriers as outlined in the policy do not conflict with the SPS Agreement, ${ }^{32}$ namely, not as an act of discrimination arbitrarily between WTO member states. ${ }^{33}$ These principles must be harmonized ${ }^{34}$ in the formation of laws and regulations so that the protection of the national interests of domestic consumers and producers can be fulfilled. Each country must understand the scientific principle as a measure in the SPS Agreement that is relevant for handling international trade that threatens security and health as a national interest, which can be justified in the general exception Article XX (b) GATT?

26 WTO, Indonesia - Importation Of Horticultural Products, Animals, and Animal Products. (https://www.wto.org/ english/tratop_e/dispu_e/cases_e/ds477_e.htm,).

27 See dispute settlement 484 (DS484) and dispute settlement506 (DS506) at https://www.wto.org/ english /tratop_e/dispu_e/cases_e/ds506_e.htm

28 Sholahuddin Al Ayyubi, "Indonesia is Again Sued at the WTO," Kembali-digugat-di-wto https://kabar24.bisnis.com/read/20190201/19/884593/indonesia-k (2019).

29 See WTO official documents G/SPS/N/CRI/230, G/SPS/N/ZAF/67, G/SPS/N/PHL/458, G/SPS/N/PHL/ 459 and $\mathrm{G} / \mathrm{SPS} / \mathrm{N} / \mathrm{JPN} / 755$. Ibid at 4.

30 See WTO official documents G/SPS/N/JPN/755, G/SPS/N/ZAF/66, G/SPS/N/BRA/1642, and G/SPS/N/ PHL/460. Ibid.

31 See WTO official documents G/SPS/GEN/1770, G/SPS/N/EU/380, G/SPS/N/RUS/184, G/SPS/N/USA/ 3135/Add.2, and G/SPS/N/TPKM/526. Ibid.

32 "WTO | Understanding the Sanitary and Phytosanitary Measures Agreement, "online: 〈https:// www.wto.org/english/tratop_e/sps_e/spsund_e.htm>.

33 Peter Van den Bossche and Werner Zdouc, The Law and Policy of the World Trade Organization: Text, Cases and Materials, Cambridge University Press, Cambridge, 2017 at 936. in Fahmi Fairuzzaman, "The Impact of the Application of the Agreement On the Application Of Sanitary And Phytosanitary Measures on Trade in Indonesia." (2018) 2: 3 Lex Renaissance Journal 321-342 at 324.

34 In Indonesia, the provisions of the SPS are the responsibility of the national Quarantine Agency, which has the task of assessing the safety and suitability of traded agricultural commodities, both those for export and those coming from abroad. It is stipulated in Law No. 16 of 1992 concerning Animal, Fish and Plant Quarantine. Demeiati Nur Kusumaningrum \& Septian Nur Yekti, "Harmonization of SPS Provisions in the Perspective of Indonesian Interests" (2018) 14: 1 Scientific Journal of International Relations 45. 
Article XX of GATT 1994 provides a chance for WTO member states to exempt the principle of non-discrimination in trade related to SPS, to enter and be trafficked in a particular country. Trade barriers Article XX.b GATT in implementing SPS protection must use the scientific principle and should not be made without adequate scientific evidence as a standard legislation policy. It is an effort to protect the law so that there is a guarantee of safety and health for imported objects, including when an infectious disease has not been found for which definitive scientific evidence has not been found as a disease that can be used as an excuse to prohibit a contaminated product from entering a country.

This study aims to understand the scientific principle of Article XX (b) GATT food safety in trade. This research's approach reviews the General Agreement on Tariffs and Trade (GATT), the Agreement of Sanitary and Phytosanitary, and the Case Approach, by examining the Dispute DS18, Dispute DS26, Dispute DS430, Dispute DS48, and Dispute DS477. ${ }^{35}$ Based on the background presented, the central part of this article discusses the scientific principle in the SPS Agreement contained in Article 2.2. Article 2.2. The SPS Agreement is further elaborated in the first subsection discusses base their measures on international standards, and the second sub-part discusses base their measures on scientific risk assessment.

\section{THE SCIENTIFIC PRINCIPLE IN THE SPS AGREEMENT}

The GATT penetrates the national domain to assess that an item has a risk value that can harm citizens so that the state can play a role in protecting citizens through trade barriers. The General Exception principle is as popular as the general law principle contained in the pacta sunt servanda principle as a legal principle in the national legal system. ${ }^{36}$ In the experience of several cases, there is debate about the application of general exception article XX (b) GATT. The general exception cannot be applied by free interpretation. However, the measure must be under the SPS Agreement and not a means of discrimination ${ }^{37}$ under the same conditions, and not constitute a veiled limitation on international trade. ${ }^{38}$ Between General exception and non-means of discrimination are two general legal principles in the agreement, so that there are conditions for applying the General exception, which must be proven that the state's act does not constitute discrimination.

The provisions of Article XX (b) GATT are further regulated in the SPS Agreement by providing conditions, including: a) based on the scientific principle and is not maintained without sufficient scientific evidence; ${ }^{39}$ b) will not be applied to arbitrary or

35 Bambang Sunggono, Normative Legal Research. (Bandung: CV. Mandar Maju, 2000) at 76.

36 JG Starke, Introduction to International Law., 13 (Jakarta: Sinar Grafika, 2014) at 97.

37 Puppis Manuel, "National media regulation in the era of free trade the role of global media governance" (2008) 23: 4 European Journal of Communication at 409.

38 Tania Voon, "Flexibilities in WTO law to support tobacco control regulation" (2013) 29: 2 \& 3 American journal of law \& medicine at 206.

39 Article 2 (2) of the SPS Agreement. 
unjustified discrimination between Members where the conditions were the same or similar effect; and c) such measures are not applied disguised restrictions on international trade. ${ }^{40}$ Each member can set own risk level from the application of SPS that can be accepted by each member based on the guideline points a) based on the scientific principle and is not maintained without sufficient scientific evidence; International standard scientific principle, as well as based on scientific risk assessment, ${ }^{41}$ as a requirement for General assessment exception. Further explanations are as follows:

\section{A. Measures on International Standards}

Trade barriers can be said to be excluded from acts of discrimination if they comply with Article 2.2 of the SPS, which is only applied to the extent that they are only to protect the life and health of humans, animals, and plants, based on the scientific principle and principles are not made without adequate scientific evidence as a standard policy of legislation. Phrases Article 2.2. SPS states, ".....based on the scientific principle and is not maintained without sufficient scientific evidence...." ${ }^{42}$ is the most frequently debated condition.

The debate is based on accepting risk by the parties or the Appropriate Level of Protection (ALOP). In order to adjust to accepting the risk, each member state is subject to a product's health value using the scientific principle. ${ }^{43}$ In order to measure these safety requirements, each member state must adopt the Alimentarius Commission codex as regulated in Attachment A3 (a) of the SPS, which states, "for food safety, the standards, guidelines, and recommendations established by the Codex Alimentarius Commission relating to food additives, veterinary drugs and pesticide residues, contaminants, methods of analysis and sampling, and codes and guidelines of hygienic practice."

Codex Alimentarius Commission (CAC) is a Food Standards Agency, an agency from the United Nations under the Food and Agriculture Organization (FAO) and the WHO, a Formal accreditation procedure. ${ }^{44}$ Codex Alimentarius is a regulation that determines the maximum limit set by institutions that make laws, institutions that set international standards, and industry groups. ${ }^{45}$ The CAC provides guidelines for risk assessment as a scientifically based process consisting of 4 steps: a. hazard identification; b. Hazard characterization; c. Exposure assessment; d. Risk characterization. It is

40 Article 2 (3) of the SPS Agreement.

41 http://www.wto.org/english/tratop_e/sps_e/sps_e.htm, and CRS Report R43450, Sanitary and Phytosanitary (SPS) and Related Non-Tariff Barriers to Agricultural Trade. In Johnson R \& Hanrahan C, "The US-EU beef hormone dispute" (2015), online: 〈https://pdfs.semanticscholar.org/a250/ ffe3524863e59dlf285eb592744f54537d33.pdf accessed on December 12, 2016.>.

42 See disputes DS26, DS48, DS320, DS321, DS231, DS477, DS478.

43 Eko Prilianto Sudradjat, Implementation of the WTO Agreement on the Application of Sanitary and Phytosanitary Measures: Analysis of the Implementation of Public Health Security and Bioterrorism Preparedness And Response Act Of 2002 by the United States (Jakarta: Legal Information Window for Trade, 2012) at 9.

44 WTO, "The WTO and the FAO / WHO Codex Alimentarius" (May 2020), online: 〈https:// www.wto.org/english/theWto_e/coher_e/wto_codex_e.htm.>.

45 Food and Agriculture Organization, "Mycotoxin Sampling Tool, User Guide, Version 1.1, 2014" (2014), online: 〈http://www.fao.org/fao-who-codexalimentarius〉. 
referred to as a "risk assessment process," i.e., a means of providing an estimate of the probability and severity of disease caused by a particular pathogen-commodity combination. ${ }^{46}$ The risk assessment proposed by CAC shows that risk can be scientifically estimated with a precise measure because each country with a test laboratory owned by each country can perform the same test so that it has the same value and conclusions regarding risk assessment.

Furthermore, risk assessments can provide information to identify and characterize food hazards so that measures of anticipation, prevention, elimination, or reduction determine the form of intervention at an acceptable level. ${ }^{47}$ For example, Codex Alimentarius provides surveillance guidelines for treating the SALMONELLA SPP bacteria in beef and pork with reference to CAC/GL 87-2016. ${ }^{48}$ Two principles that must be taken into account in this guideline are: First, the Principle of Analysis on food safety risks (for example) is carried out by adjusting in /guide the salmonella control on beef and pork from the production of origin to consumption. The application of measures based on science and risk assessment must be reflected in the prevention and control of pollution in meat production and processing.

The application of the principles of Hazard Analysis and Critical Control Point System and Guidelines for its Application (HACCP) is an integral part of pollution prevention and control efforts. ${ }^{49}$ HACCP principles do not stand alone; this principle is closely related to activities' complexity to achieve clean meat. It can collaborate with other Codex-related, such as the principle of inspection and certification of imported food (CAC/GL 20-1995). ${ }^{50}$ Collaboration that is enforced between countries in applying standard standards for goods allowed to enter their countries varies; it must be determined in advance in the laws and regulations of WTO member states and then notified to the WTO so that all exporting countries know the standards that are enforced through regulations. which has been notified.

Second, where possible, regulatory authorities should formulate metrics ${ }^{51}$ on risk management so that they can objectively disclose the level of Salmonella control in beef and pork required for public health purposes. The principles of food safety risk management must be included in the design of the meat hygiene program implementation. The work carried out by the Joint FAO/WHO Expert Meetings on Microbiological Risk Assessment (JEMRA), The Joint FAO/WHO Expert Committee on Food Additives (JECFA), and FAO/WHO Expert Consultations has resulted

46 FAO, "ANNEX 7. Introducing JECFA, JMPR, JEMRA, and GM Food Risk Assessment", online: 〈http://www.fao.org/3/y8705e/y8705e0d.htm〉.

47 Ibid.

48 Codex Alimentarius, "Guidelines For The Control of Nontyphoidal Salmonella SPP. In Beef and Pork Meat”, (2016), online: http://www.fao.org/fao-who-codexalimentarius/standards/list-of-standards/ $\mathrm{en} / \mathrm{s}$.

49 Ibid at 3.

50 Ibid at 4.

51 Codex Alimentarius, "Principles and Guidelines for the Conduct of Microbiological Risk Management (MRM) (CAC/GL 63-2007)”, (2013), online: 〈http:/www.fao.org/fao-who-codexalimentarius/ standards/list-of-standards/en/. 
explicitly in risk management recommendations that should be considered. ${ }^{52}$ An example is the guideline codex Microbiological Risk Management (MRM)(CAC/GL 632007), which can be used as a reference in a series of risk management in implementation design. ${ }^{53}$ In this case, the authorized party is the National Quarantine Agency based on Law No. 16 of 1992 concerning Animal, Fish, and Plant Quarantine, has the responsibility to recommend provisions that serve as guidelines for importers.

\section{B. Measures On Scientific Risk Assessment}

The SPS Agreement recognizes states' right to maintain standards, ${ }^{54}$ with more stringent than international standards. Thus, Article 3.3 of the SPS states that members may introduce or maintain SPS measures that result in a higher level of SPS protection than achieved through measures based on international standards, relevant, guidelines, or recommendations.

Scientific justification is further regulated in articles 5.1, 5.2, and 5.7 SPS. Article 5.1 of the SPS states, "Members must ensure that Their SPS measures are based on a risk assessment, which is appropriate to the conditions for risks to human life and health to animals and plants, taking into account risk assessment techniques developed by relevant international organizations." The definition of risk assessment is set out in Appendix A (4) SPS states, "risk assessment is a. Evaluation of the possibility of entry, formation or spread of pests or diseases within the territory of the importing member state under the SPS policy applied, and the potential related biological and economic consequences; $b$. evaluation of potential adverse effects on human or animal health arising from the presence of additives, contaminants, toxins, or disease-causing organisms in food, beverages, or feedstuffs." The risk assessment set out in Annex A (4) of the SPS is further elaborated.

First, evaluate the possibility of entry, formation, or spread of pests or diseases within an importing member state's territory following applicable SPS policies and related potential biological and economic consequences. A case study on the risk assessment of the DS18, Canada questions Australia's ban on imports of fresh, chilled, or frozen salmon. The measure at issue is Australia's ban on imports of fresh, chilled, or frozen salmon to protect domestic salmon populations from several diseases. Canada claims that salmon imported for human consumption is very likely the cause of this disease's introduction. The Appeal Board affirms that likelihood means probability, and that demonstration of a possible entry of a pest or disease alone does not adequately meet the need for a risk assessment for risks arising from pests and diseases, as defined by the SPS Agreement. Therefore, The Appellate Body determines that Australia has violated Articles 5.1 and 2.2 of the SPS Agreement.

A case study on risk assessment in DS430, the United States questioned India about the ban on imports of fresh poultry meat and eggs from countries indicated by low

52 Ibid at 4.

53 Ibid.

54 WTO, "Detailed Presentation of Risk Assessment and Level of Protection related to SPS," online: 〈https://ecampus.wto.org/admin/files/Course_385/Module_1509/ModuleDocuments/SPS_Risk-L2-RlE.pdf.>. 
pathogenetic disease. The Appeal Board (DS430) concluded on its finding that India's AI measures were inconsistent with Articles 5.1 and 2.2, as such measures were based on "indicated country information," and were not based on an SPS risk assessment. ${ }^{55}$ Article 2.2 and Article 5.1 of the SPS must be read together because Article 2.2 focuses on the essential obligations of the SPS Agreement, while Article 5.1 is the specific implementation of Article 2.2.56 Articles 2.2 and 5.1 are cumulative, which must be followed as part of the agreed standard.

Second, evaluating potential adverse effects on human or animal health arises from additives, contaminants, toxins, or disease-causing organisms in food, beverages, or feedstuffs. Some of the disputed case studies relating to the evaluation of potential adverse effects in this regard are:

1. Risk assessment case study on DS26 and DS48, United States and Canada questioned the European Community's ban on imports of hormone-treated beef for food safety reasons. ${ }^{57}$

2. Case study risk assessment in DS203, Mexico has banned pigs' imports if the pigs exceed 110 kilograms of body weight. Mexico is suspected of maintaining sanitary restrictions, including inspection and quarantine measures, on imports of pigs weighing 110 kilograms. ${ }^{58}$

3. The risk assessment case study on DS477, New Zealand, questions Indonesia's restrictions on imports of Horticultural Products, Animal and Animal Products according to "storage capacity." The Panel's report on DS477, states that the requirement to "have a certain storage capacity" is not a measurement based on section 5.1 of the SPS on risk assessment

In this case, the Appellate Body applies two test measures to assess the risk of covered food by identifying the effect of health in humans or animals arising from additives and contaminants. If these side effects are present, then it is followed by evaluating the potential for these effects. ${ }^{59}$ Tests of risk assessment measures are listed in the Court's report on DS26, DS48, DS203, and DS477 above that the risk in question must be certain, theoretical uncertainty does not include the elements of Article 5.1. The risks borne must be specific. There are requirements for these specifications; for example, the risk of concern cannot be included as a general hazard, or overcome the whole. The risks associated with the combination of all diseases necessary. Finally, the risk assessment must be comprehensive and covers every product in question. The example of the Panel's decision in the DS26 case has stated that assessment risk must be carried out for each problem's substance. ${ }^{60}$ However, in some instances, the Panel concluded

55 WTO, "India - Measures Concerning The Importation Of Certain Agricultural Products" (2017), online: 〈https://www.wto.org/english/tratop_e/dispu_e/cases_e/ds430_e.htm〉.

56 Eun Sup Lee, Sun Ok Kim \& Zhu Zhu, "Scientific Principle under the SPS Agreement." (2010) 9: 1 Pacific Rim Law \& Policy Journal, Vol. 9 at 151.

57 WTO, supra note 54 at 6.

58 WTO, "Mexico - Measures Affecting Trade in Live Swine" (2000), online: 〈https://www.wto.org/ english/tratop_e/dispu_e/cases_e/ds203_e.htm.>. see also DS524, DS477, DS478

59 WTO, supra note 54 at 6.

60 Ibid at 7. 
that the risk assessment carried out for one product category may be relevant to another category if it is subject to the same type. An example of the Panel's decision on the Salmon Australia case stated that a study of one particular product category could be relevant for risk assessment about other product categories.

Scientific justification is further regulated in Article 5.2 of the SPS Agreement, In risk assessment, Members must consider available scientific evidence; relevant production methods and processes; relevant inspection, sampling, and test methods; the prevalence of certain diseases or pests; The existence of areas that are infected or free from disease; relevant ecological and environmental conditions; and quarantine or other treatment." The Appellate Body states Article 5.2 indicates that risks are assessed under Article 5.1 "risks, ascertained not only in science laboratories operating under highly controlled conditions, but also risks that humans experience in society because they actually exist, in other words, the potential for adverse effects on human health in the real world where people live and work and die "(Appellate Body reports DS26, DS48, and Panel DS477 report).

It is important to note that Article 5.2 is not rigid. Risks related to detection and control of compliance with certain requirements are also taken into account as part of risk assessment. Thus, risk assessment is defined as a "scientific process" for examining the distribution and magnitude of possible risks instead of "risk management" for employing risk assessment and many other factors to determine and achieve an appropriate level of risk. This risk assessment is not based on "theoretical risk ${ }^{61}$

Scientific justification is further regulated in Article 5.7 SPS, "If there is insufficient relevant scientific evidence, Members may temporarily adopt SPS measures or standards based on relevant information available, including those from relevant international organizations as well as from the actions of the SPS applied by other members. It is an effort to "prevent" an outbreak like COVID-19 to not further spread into the country. In such circumstances, the member shall take the measures already available to obtain additional information in the risk assessment to be more objective, and review the SPS measures accordingly within a reasonable timeframe. "

Temporary measures could be taken by members, such as when a disease outbreak first spreads, or activity could be undertaken as an emergency response to a sudden disease outbreak, suspected of being import-related. In contrast, further information on the source of the outbreak and its reach is still being collected. The risk assessment's reasonable discretion in making decisions on sanitary or phytosanitary measures is provided in Article 5.7 of the SPS. WTO Members can apply this principle by providing a level of protection for human health, animals, and plants that improve the protection achieved by measures based on international standards, guidelines, or recommendations relevant, but this activity must be accountable scientifically. It may also be done under certain conditions, such as new food processing techniques, where sufficient safety evidence does not yet exist.

61 Eun Sup Lee, Sun Ok Kim, and Zhu Zhu supra note 56. 
Several cases relating to Article 5.7 are Japan-Agricultural Products II (also referred to as Japan-Varietals, WT/DS76), Japan-Apples (Japan-Measures Affecting the Importation of Apples, WT/DS245), EC-GMOs (European Communities-Measures Affecting the Approval and Marketing of Biotech Products, WT/DS291, 292, 293), ${ }^{62}$ Russia - Pigs (EU) (Russian Federation-Measures on the Importation of Live Pigs, Pork and Other Pig Products, WT/DS475), ${ }^{63}$ and Korea - Radionuclides (Korea-Import Bans, and Testing and Certification Requirements for Radionuclides, WT/DS495). ${ }^{64}$

Report The Appellate Body in cases guide the interpretation of Article 5.7 in implementing temporary measures in the event of an outbreak that threatens the national interest. The applied trade policy must contain four conditions that must be met cumulatively and legally implemented by applying it in legislation and notifying the WTO, the conditions that must exist, including:

a. Article 5.7 SPS standards should be applied to situations, where relevant scientific information is not sufficient;

b. interim standards should be adopted based on the relevant information available;

c. members should take existing standards for additional information on risk assessments to be more objective.

d. members should review SPS standards accordingly within a reasonable timeframe. ${ }^{65}$

Relevant scientific information comes from the competent authority relating to a specific matter, such as the WHO is the guideline reference for each country in applying Article 5.7. The Appellate Body's through the interpretation of Article 5.7, shows that the principle of prudence is still carried out on two sides, namely prioritizing the balance of the risk or impact of damage (on safety and health) and the side of non-discrimination as a basic principle of the WTO Agreement. This is reflected in Article 5.7, point d, which requires members to evaluate the SPS's size according to a specific period.

\section{CONCLUSION}

The scientific principle ensures food safety Article XX (b) GATT, as outlined in the SPS Agreement implemented in two ways. First, it bases the measure in international standards. Each WTO member can establish the desired national regulation with a standard of capability that can be implemented by member states to determine the appropriate level of protection using standards issued by the CAC. Codex Alimentarius formed food safety risk analysis through the HCCP process, and the second way is to formulate risk management metrics that have been recommended by JEMRA, JECFA, and FAO/WHO Expert Consultations. Second, scientific principle ensures food safety in

62 WTO, supra note 54 at 23. See also case DS475 and DS495.

63 WTO, "Russian Federation - measures on the importation of live Pigs, Pork And Other Pig Products From The European Union," (2016), online: 〈https://www.wto.org/english/tratop_e/dispu_e /475r_e. pdf.>.

64 WTO, "Korea - Import Bans, And Testing And Certification Requirements For Radionuclides", (2015), online: 〈WWW.WT / DS495 / 3 KOREA - docs.wto.org.〉.

65 Ibid at 24. 
the SPS Agreement, as carried out with the base of measures on scientific risk assessment, carried out with regulated scientific justification Article 5.1 in conjunction with Attachments A (4), Articles 5.2, and 5.7 SPS. Thus, each country can choose a food safety protection mechanism to protect its citizens but still within the scientific principle.

\section{ACKNOWLEDGMENTS}

None.

\section{COMPETING INTERESTS}

The authors declare that they have no competing interests.

\section{REFERENCES}

Adiwibowo, Yusuf. "Technical Barrier to Trade Rokok Kretek Indonesia dalam Measures Affecting the Production and Sale of Clove Cigarettes Amerika Serikat (DS-406)" (2013) 1:2 Jurnal IUS 235-244.

Al Ayyubi, Sholahuddin. "Indonesia Kembali Digugat di WTO”, https://kabar24.bisnis. com/read/20190201/19/884593/indonesia-kembali-digugat-di-wto (2019).

Brown, Valerie J Atkinson. Legal research via internet (Canada: Thomson Delmar Learning, 2001).

Hutchinson, Terry. Researching and Writing in Law (Lawbook Co, 2002).

McGrady, Benn. Trade and Public Health: The WTO, Tobacco, Alcohol, and Diet (Cambridge University Press, 2011).

Raju, K D. World Trade Organization Agreement on Anti-dumping: A GATT/WTO and Indian Jurisprudence (The Netherlands: Kluwer Law International B.V., 2008).

Sefriani. Peran Hukum Internasional dalam Hubungan InternasionalKontemporer (Jakarta: Rajawali Pers, 2016).

Starke, JG. Pengantar Hukum Internasional., 13 (Jakarta: Sinar Grafikan, 2014).

Sudradjat, Eko Prilianto. Penerapan WTO Agreement on the Application of Sanitary and Phytosanitary Measures: Analisis Tentang Penerapan Public Health Security And Bioterrorism Preparedness And Response Act Of 2002 oleh Amerika Serikat (Jakarta: Jendela Informasi Hukum Bidang Perdagangan, 2012).

Sunggono, Bambang. Penelitian Hukum Normatif (Bandung: CV. Mandar Maju, 2000). Adiwibowo, Yusuf. "Technical Barrier to Trade Rokok Kretek Indonesia dalam Measures Affecting the Production and Sale of Clove Cigarettes Amerika Serikat (DS-406)" (2013) l:2 Jurnal IUS 235-244.

Costa, José Augusto Fontoura. "Data Protection in International Trade Law" in Dário Moura Vicente \& Sofia de Vasconcelos Casimiro, eds, Data Protection in the Internet Ius Comparatum - Global Studies in Comparative Law (Cham: Springer International Publishing, 2020) 479. 
Darbandi, Elham, Riza Radmehr \& Sayed H Saghaian. "The Impact of Consumer Beef Safety Awareness on U.S. Beef Exports" (2020) The International Trade Journal, online: 〈https://doi.org/10.1080/08853908.2020.1742255〉.

Fairuzzaman, Fahmi. "Dampak Penerapan Agreement On The Application Of Sanitary And Phytosanitary Measures Terhadap Perdagangan di Indonesia.” (2018) 2:3 Jurnal Lex Renaissance 321-342.

Ginige, Tilak et al. "Harnessing marine renewable energy from Poole Harbour: a case study” (2013) 6:1-3 International Journal of Liability and Scientific Enquiry 1-26.

Gonzales, Carmen G. "Institutionalizing Inequality: The WTO Agreement on Agriculture, Food Security, and Developing Countries." (2002) 27:2 Columbia Journal of Enfironmental Law 435-489.

Hoffman, Steven J \& Trygve Ottersen. "Addressing antibiotic resistance requires robust international accountability mechanisms" (2015) 43:3 The Journal of Law, Medicine \& Ethics.

Karantina, Badan. "Sekilas Sanitary and Phytosanitary (SPS) Measures", Badan Karantina Pertanian Kementrian Pertanian Republik Indonesia, online: 〈https://karantina.pertanian.go.id/page-20-sekilas-sps.html.〉.

Kusumaningrum, Demeiati Nur \& $\&$ Septian Nur Yekti. "Harmonisasi Ketentuan SPS dalam Perspektif Kepentingan Indonesia” (2018) 14:1 Jurnal Ilmiah Hubungan Internasional 45.

Lee, Eun Sup, Sun Ok Kim \& Zhu Zhu. "Scientific Principle under the SPS Agreement." (2010) 9:1 Pacific Rim Law \& Policy Journal, Vol9 151.

Manuel, Puppis. "National media regulation in the era of free trade the role of global media governance" (2008) 23:4 European journal of communication 409.

Paull, John. "Genetically Modified Organisms (GMOs) as Invasive Species" (2018) 4:3 Journal of Environment Protection and Sustainable Development 31-37.

R, Johnson \& Hanrahan C. "The U.S.-EU beef hormone dispute", (2015), online: 〈https://pdfs.semanticscholar.org/a250/ffe3524863e59dlf285eb592744f54537d33 .pdf accessed on December 12th 2016.>.

Sabaruddin, Sulthon Sjahril. "Dampak Perdagangan Internasional Indonesia terhadap kesejahteraan Masyarakat: Alikasi Structural Path Analysis" (2015) 17:4 Buletin Ekonomi Moneter dan Perbankan.

Sefriani. "Pengaturan Perdagangan Jasa Internasional Dalam DATS/WTO" (2005) 28:12 Jurnal Hukum 129-146.

Silva, Alice Rocha da \& Mario Abrahão Antônio. "A aplicação do princípio da precaução ante os riscos advindos das novas tecnologias bélicas" (2018) 8:1 RBPP 745-765.

Stevens, Mary. "The Precautionary Principle in the International Arena" (2002) 7:2 Sustainable Development Law \& Policy 13-22.

Sujianto, Agus Eko \& Muhammad Fajar Ulil Azmi. "Associative Study on Government Spending, Inflation, Trade Balance, and Gross Domestic Product” (2020) 15:1 Ekuilibrium: Jurnal Ilmiah Bidang Ilmu Ekonomi 27-37. 
Tonsor, Glynn T et al. "Consumer valuations of beef steak food safety enhancement in Canada, Japan, Mexico, and the United States." , Vol.57, Issue. 3, August 2009: p. 396" (2009) 57:3 Canadian Journal of Agricultural Economics/Revue canadienne d'agroeconomie 395-416.

Voon, Tania. "Flexibilities in WTO law to support tobacco control regulation" (2013) 29:2 \& 3 American journal of law \& medicine.

Codex Alimentarius. "Guidline s For The Control of Nontyphoidal Salmonela SPP. In Beef and Pork Meat.", (2016), online: 〈http://www.fao.org/fao-whocodexalimentarius/standards/list-of-standards/en/>.

Codex Alimentarius. "Principles and Guidelines for the Conduct of Microbiological Risk Management (MRM) (CAC/GL 63-2007).”, (2013), online: 〈http:// www.fao.org/fao-who-codexalimentarius/standards/list-of-standards/en/>.

Food and Agriculture Organization. "Mycotin Sampling Tool, User Guide, Version 1.1, 2014", (2014), online: 〈http://www.fao.org/fao-who-codexalimentarius〉.

Wartini, Sri. "Sri Wartini, 'Implementasi Prinsip Kehati-hatian dalam Sanitary and Phythosanitary Agreemant, Studi Kasus: Keputusan Appellate Body WTO Dalam Kasus Hormone Beef Antara Uni Eropa Dengan Amerika Serikat', Jurnal Hukum, Vol. 14 No. 2, 2007, hlm. 298.", online: 〈https://journal.uii.ac.id/IUSTUM/article/ view/1074>.

WTO. Indonesia - Importation Of Horticultural Products, Animals And Animal Products. 〈https://www.wto.org/english/tratop_e/dispu_e/cases_e/ds477_e.htm>.

WTO. The WTO and the FAO/WHO Codex Alimentarius, (2020), online: 〈https:// www.wto.org/english/theWto_e/coher_e/wto_codex_e.htm.>.

WTO. Detailed Presentation of Risk Assessment and Level of Protection related to SPS, online: 〈https://ecampus.wto.org/admin/files/Course_385/Module_1509/Module Documents/SPS_Risk-L2-R1-E.pdf.>.

WTO. India - Measures Concerning The Importation Of Certain Agricultural Products, (2017), online: 〈https://www.wto.org/english/tratop_e/dispu_e/cases_e/ds430_e. htm>.

WTO. Mexico - Measures Affecting Trade in Live Swine, (2000), online: 〈https:// www.wto.org/english/tratop_e/dispu_e/cases_e/ds203_e.htm.>.

WTO. Russian Federation - measures on the importation of live Pigs, Pork And Other Pig Products From The European Union, (2016), online: 〈https:/www.wto.org/ english/tratop_e/dispu_e/475r_e.pdf.>.

WTO (7). Korea - Import Bans, And Testing And Certification Requirements For Radionuclides, (2015), online: 〈WWW.WT/DS495/3 KOREA - docs.wto.org.〉.

WTO. Dispute Settlement Understanding - legal text, online: 〈https:/www.wto.org/ english/tratop_e/dispu_e/dsu_e.htm $\$ 22$.

WTO. Sanitary and Phytosanitary Measures - text of the agreement, online: 〈https://www.wto.org/english/tratop_e/sps_e/spsagr_e.htm〉.

WTO. Technical Barriers to Trade - TBT official documents, online: 〈https:// www.wto.org/english/tratop_e/tbt_e/tbt_notifications_e.htm>. 
187 | LENTERA HUKUM

WTO. Understanding the Sanitary and Phytosanitary Measures Agreement, online: 〈https://www.wto.org/english/tratop_e/sps_e/spsund_e.htm〉.

WTO. Understanding the WTO - Standards and safety, online: 〈https:/www.wto.org/ english/thewto_e/whatis_e/tif_e/agrm4_e.htm>. 
188 | The Scientific Principle of Food Safety in the Agreement on Sanitary and Phytosanitary Measures

This page is intentionally left blank 